\title{
Undergraduate Students' Experiential Motives when Expressing Bajingan as Their Expletive
}

\author{
Didik Rinan Sumekto; Kustinah \\ English Education Department, Widya Dharma University, Indonesia \\ Corresponding Email: didikrinan@unwidha.ac.id
}

\begin{abstract}
This research aims to investigate students' acknowledgments on bajingan meanings and expletive motives revealing at their experiential life. One hundred and seventy-seven undergraduate students majoring in English, Javanese, and Indonesian participated in this study. Data were collected from the closed and opened questionnaires focusing on the self-rated perception of Scherer and Sagarin's (2006) ten expletive motives, and Nicolau and Sukamto's (2013) male and female attitudes toward the expletive. The analyses used the descriptive and non-parametric statistics. The minor differences among four expletive motives were found, on the other hand, the motive of acting cool indicated a significant difference $(p=.000)$. The negative $Z$ value for anger expression, $Z=-1.910$, peer pressure, $Z=-.875$, tensions and frustrations relief, $Z=-1.567$, part of acting cool, $Z=-3.607$, and society acceptance, $Z=-.225$. The findings also indicated $10.2 \%$ females and $.7 \%$ males recognized bajingan as a wagon driver, whereas $70 \%$ females and $25 \%$ males stated it as an expletive. Males showed a predominant expletive more than females toward male and mixed gender. The TV program was believed as the mostly influenced media to triggering the expletive expression. This expletive deals with the intra-and inter-individual contexts deducing the positive or negative reactions.
\end{abstract}

Keywords: Bajingan; expletive; motives; personal experience; polysemy

\section{INTRODUCTION}

People using a finite vocabulary can express a nearinfinite number of sentiments since some words can express a range of different ideas in different situations (Hoffman, Ralph, \& Rogers, 2013) and have different meaning for different context, but were similarly spelled and pronounced, so-called by the polysemous words (Shallu \& Gupta, 2013). The polysemy of bajingan is understood to have two different meanings with subtle shifts in meaning that describes an alternative meaning and varies continuously as its context function (Hoffman, Ralph, \& Rogers, 2013) and runs through all sense of definitions (Verspoor \& Lowie, 2003). The first meaning refers to a wagon driver and the second one is widely understood as an expletive. This induces a relation of consequence, and understood as the relation of truth- preservation (Peregrin, 2010), and can be slight and/ or non-existent meaning for the majority of empirical vocabulary (Elston-Güttler \& Williams, 2008).

Being engaged in the polysemy, English words interestingly indicate the multiple different meanings. For example, the word of break can mean to separate into pieces or to take a rest from work (Khanna \& Cortese, 2011) and bark can refer to the sound made by a dog or to a tree covering, in which the correct interpretation depends entirely on the linguistic and conditional context (Hoffman, Ralph, \& Rogers, 2013). However, the polysemous relationships of meaning are no longer needed in terms of being related as the means of etymological arguments but they can be posited with reference to empirically established diachronic clines 
(Andrason \& van der Merwe, 2015). Thus, the reason for the ubiquity of polysemous words leads some people preferred to take words and extend their meaning rather than creating new words (Crossley, Salsbury, \& McNamara, 2010).

In the contexts of bajingan meaning, there has been well-recognized for years by Indonesians' various ages through their daily communication influences and open sources, such as Google, Yahoo, and Wikipedia. The later, this word becomes popular in either Javanese or Indonesians as an expletive. As one of the linguistic studies, this reality examines the polysemous contribution which reflects the history and degradation of word meaning. Trends continually regards that bajingan is well-determined to reflect a bad person, bastard, or uncivilized person. However, the former meaning was used to acknowledging the wagon driver (Indonesian: sopir gerobak or cikar sapi), one of the traditional vehicles which are carried by the $\operatorname{cow}(\mathrm{s})$ and driven by some local residents. In terms of the wagon driver, bajingan is commonly familiar among local communities. During its furtherance, a bajingan gradually descended into a different connotation as this vehicle's trip has taken times and its estimated time arrival is unpredictable. Consequently, this situation takes people to be impatient to stay for a ride. In a particular moment, bajingan lately refers to an expletive. This expletive used to be wellexpressed in an analog to express someone's belatedness. For example, the following expression commonly happened in a warm communication moment, "where have you been? You are terribly late like bajingan" (Javanese: Seko ngendi waé kowé, suwé tenan kaya bajingan).

Attitudes toward spoken language vary tremendously within the population growth in Indonesia. In regards to the influencing factors, such as age, gender, ethnicity, social status, and region. Group (2005) considers these factors have an effect on views of what constitutes an offensive language. The expletive is defined as an offensive word, especially used as an expression of anger, surprise, agreement, contradiction, provocation, insulting somebody, strengthening a statement, and joy. It is regarded as a socially taboo word or phrase of a profane, obscene, or insulting character (Gati, 2014). Anderson and Trudgill (2007; Vingerhoets, Bylsma, \& De Vlam, 2013) define the expletive as a language used refers to swearer's culturally stigmatized expression, which is used to express strong emotions or attitudes. Reflecting the phenomena of bajingan meaning, this accordingly substitutes the negative connotation of indicating bastard or uncivilized persons, as Butler (2010) apparently believes that bastardy was considered as a crime against a community's moral values.

However, the expletive issues were formally studied in 1901 (Johnson \& Lewis, 2010) and universally expressed in both direct communication context and people's general belief which present in a culture, inappropriateness, and offensiveness consideration (Gati, 2014), and often regard as a bad language and deemed inferior to the standard expression (Lantto, 2014), as well as considered in a taboo culture's area (Hagen, 2013; Anderson \& Trudgill, 1990; Gati, 2014), although some people still consider it as a sense of humor emphasis instead of creating an anger (Livni, 2016), in which this was controlled and restricted by the societal norms. Being considered as a bad word and an unnecessary linguistic feature, this expletive considerably corrupts a language system, sounds unpleasant and uneducated (Karjalainen, 2002), and regards as an offensive (Hagen, 2013).

So far, the expletive is commonly expressed to affirm their identity in a group, as to strike, to joy, to disrespect, to show friendship, to indicate social solidarity, and as instances of harsh, unpleasant, and offensive words (Karjalainen, 2002), besides emotion of being angry, upset, shocked, or happy (Hagen, 2013). This means that genders potentially express the expletive as if they are prominent features in the context of certain motives (Gati, 2014). To understand beyond the expletive use, Scherer and Sagarin (2006) identify ten expletive motives, such as expressing anger, emphasizing feelings, doing out of habit, causing peer pressure, relieving tensions and frustrations, indicating taboo, acting cool, getting attention, since these words were acceptable, and lacking of another word. These motives otherwise depend on the individuals' experience who adjudged to be generally deviant and exotic, and mainly perceived as a mark of conditionally poor parentage or family, highly unemployed rates, limited education, low social orientation (Mensah, 2012), speech rate, class background, geographic location, accent, lexical provenance, mood of the speaker, physical appearance, gender, a person's expertise, the context of where language is spoken (Hagen, 2013), emotional awareness and gender perspectives, and how old, religious, and impulsive people are (Gati, 2014). These backgrounds confirmed each individual and expressed users' deviant tendencies against established norms and conventions. As reflected by (Pavlenko, 2008), the function was on contextualization cues either to increase or decrease emotions in the context, where individuals revealed their most private thoughts, feelings, memories, and experiences.

An experiential expletive is indicative significantly 
and conditionally. An expletive switches the mindset, as occurring in situations when a swearer expresses a particularly strong attitude to others rather than showing aggression (Praschinger, Pomikal, \& Stieger, 2011). It can be also functioned as an affectionate teasing among best friends (Jay \& Janschewitz, 2008), as a way of showing enthusiasm or simply as a cathartic way to release frustration (Manchón, 2013), and a particular function of conscious control (Vingerhoets, Bylsma, \& De Vlam, 2013). Jay and Janschewitz (2008; Dynel, 2012) conceptualize a propositional expletive creates a planned, intentional and controllable moment, whereas non-propositional refers to unplanned, unintentional, and uncontrollable moment. This seems to be a mirror cathartic expletive. According to Jay (2009), the ultimately offensive words are commonly addressed by the pragmatic variables, such as the speaker-hearer relationship and social-physical setting, and the voice tone. However, the offensiveness can insult somebody or a group of people through the aggressive attacks against some cultures, societal sub-groups, races, or ideology in a tirade (Razavi, Inkpen, Uritsky, \& Matwin, 2010) that constitutes the basis of the decision (Praschinger, Pomikal, \& Stieger, 2011).

Further, Jay (2009) points out that the expletive expression have been experienced in the lexical social groups, such as soldiers, policemen, sailors, high school and college students, drug users, athletes, laborers, juvenile delinquents, psychiatric patients, and prisoners; although the number of the expressions rates are not observable and documented yet. Nicolau and Sukamto (2013) specifically record that an expletive is not identically used as the behaviors of uneducated or low-social class people. All social status, either men or women, with no social boundaries are likely to express expletives. For instance, saying bajingan is not forbidden, but is controlled in the manner of when and where to say it, and sometimes the right persons who say this expletive word will refer to certain attention among others. Karjalainen (2002) depicts another situation if a man incidentally drops a wrench on his foot, he probably feels a certain accumulation of pain, but he is not enough to lose control. However, this can lead an emotion to express frustration and anger by swearing shit, damn it or fuck. Thus, Vingerhoets, Bylsma, and De Vlam (2013) agree if the best suited expletive context seems to be an informal setting with the familiar people of equal status and genders. Hence, the connotative interpretations that are possible for bajingan as an expletive, influence much about the socio-cultural conditions reflecting the swearers (Mercury, 1995) and more tolerated in informal and private or group settings (Vingerhoets, Bylsma, \& De Vlam, 2013).

Some researches constituted the use of expletive that became a trend of people who habitually expressed their motives. Bowers and Pleydell-Pearce (2011) differentiated the emotional forces toward the swearwords and euphemisms that contrasted the semantic and/ or pragmatic distinctions. The emotional forces toward the swearwords perception in the multilingual different languages were individually influenced by the linguistic performance, such as how and when the language was learned, what general level of activation did the language(s) have, how frequently had the language been used (Dewaele, 2004). For example, an expletive of motherfucker was consistently rated as the most offensive among both sexes and across all races (Fägersten, 2007). On the other hand, Gati (2014) believed that the main function of the expletive among women is to show an expression of anger, surprise, and interjection through the expletive of Oh God! Shit! and Fuck! Next, Johnson and Lewis (2010) explored their findings in terms of hearers viewed an expletive expression informal setting was more unexpected than expressing an expletive in social gatherings, although a particular expletive was more acceptable in particular workplace interaction.

In today's phenomena, the word of bajingan has both incidentally and habitually been heard in the societal communications. Most students with the Javanese and other backgrounds are familiar with this word, although the perspectives of expressing bajingan contexts and motives among them are still debatable. Thus, this present research aims to investigate whether students' acknowledgments on its meaning and expletive motives become trends in their experiential life when using bajingan. Hence, four research questions are accordingly regarded in the following emphasis: (1) What are the most influential motives among students when they expressed this expletive? (2) Can students definitely differentiate the polysemy of bajingan? (3) In what gender-based groups do the use of bajingan frequently appear as an expletive? and (4) In students' perceptions, what media have dominantly influenced them to express this expletive?

\section{METHODS}

Participants were undergraduate pre-service teachers from English, Javanese, and Indonesian majors. Intentionally, the reason for choosing the undergraduate pre-service teachers from three majors was just they were vulnerable groups who potentially express bajingan as their expletive. They were active students in 2016/2017 
academic enrollment at Widya Dharma University, Klaten, Indonesia. 177 voluntarily participants contributed to the database; $72 \%(n=127)$ females and $28 \%(n=50)$ males respectively from the totally returned questionnaires. Their age ranged in between 17to30years old (Mage $=23.5$; $S D=9.192$ ) at the time of completing the questionnaires Of the participants involved in this research, they were 17 years old as the youngest participants, $2 \%(n=3)$; 18 years old, $12 \%(n=22) ; 19$ years old as the most common age, $23 \%(n=41) ; 20$ years old as the majority of participants, $27 \%(n=49) ; 21$ years old, $18 \%(n=$ $32) ; 22$ years old, $9 \%(n=15) ; 23$ years old, $4 \%(n=$ 7); 24 years old, $3 \%(n=5) ; 25$ years old, $1.1 \%(n=2)$; and 30 years of age as the oldest participant, $.6 \%(n=1)$. The ethnicity-based data were 171 (97\%) participants of the population from which the samples were drawn had identified themselves as Javanese, whilst only 6 (3\%) of the participants were Bangka, Batak, Dayak, Madurese, Sundanese, and Sasak. Over half of 130 (73\%) participants were notified that they were born in Klaten, whilst other $46(26 \%)$ participants were born in other towns in Indonesia.

Data were collected from the self-rated perception of Scherer and Sagarin's (2006) ten expletive motives and Nicolau and Sukamto's (2013) male and female attitudes toward the expletive. Part one of the questionnaire consisted of ten closed questions with a 5-point Likert scale and part two consisted of three open questions the participants indicated their responses. Out of ten expletive motives, five motives had fulfilled the research instrument that was previously examined toward other 30 undergraduate pre-service teachers majoring in English, Javanese, and Indonesian education through Cronbach's alpha reliability coefficient test (Cronbach, 2004). The results were in between .304 to .494 with the significance level at $p<.30$. The Cronbach's alpha $(\alpha)$ was .494 for expressing anger, .345 for being caused by peer pressure, .451 for tensions and frustrations relief, .304 for being part of acting cool, and .312 for society acceptance on the swearword. The instruments' reliability were also analyzed by the Spearman's rho with the significance level at $p<.01$. Data analysis used the descriptive statistics to analyze gender's inter-group perception Ary, Jacobs, and Sorensen (2010), Chi-square test, and Mann-Whitney U test, as bivariate analyses among participants' sex and expletive frequency (Neuman, 2006;Stevens (2009).

\section{FINDINGS AND DISCUSSION Descriptive Analysis}

The results of the descriptive statistics accordingly analyzed Scherer and Sagarin's (2006) expletive motives. The analysis corresponded with the frequencies and percentages. The summary firstly began with the anger expression that revealed $(M=2.520 ; S E=.058 ; S D=.769)$. The anger expression motive remarkably noticed that 1 $(.6 \%)$ participant was very frequent, $8(4.5 \%)$ participants were frequent, $92(52 \%)$ participants were sometimes, and $57(32.2 \%)$ participants were seldom expressing bajingan. On the other hand, 19 (10.7\%) participants never expressed bajingan as their expletive. Secondly, the motive relied on the peer pressure $(M=2.158 ; S E$ $=.072 ; S D=.958)$. This peer pressure motive recorded that $2(1.1 \%)$ participants were very frequent, $12(6.8 \%)$ participants were frequent, $49(27.7 \%)$ participants were sometimes, and 63 (35.6\%) participants were seldom expressing bajingan. Meanwhile, 51 (28.8\%) participants never expressed bajingan as their expletive. Thirdly, the motive clarified the tensions and frustrations relief $(M=$ $2.243 ; S E=.067 ; S D=.931)$. This motive showed that 1 (.6\%) participant was very frequent, $11(6.2 \%)$ participants were frequent, $64(36.2 \%)$ participants were sometimes, and $55(31.1 \%)$ participants were seldom expressing bajingan. On vice versa, 46 (26.0\%) participants never expressed bajingan as their expletive. Fourthly, the motive relied on part of acting cool $(M=2.153 ; S E=$ $.084 ; S D=1.115)$. It was found that $2(1.1 \%)$ participants were very frequent, 23 (13\%) participants were frequent, $44(24.9 \%)$ participants were sometimes, and $39(22 \%)$ participants were seldom expressing bajingan upon a part of acting cool motive. However, 69 (39\%) participants never expressed bajingan as their expletive. Last but not least, the society acceptance motive decided $(M=2.565$; $S E=.094 ; S D=1.247)$. This society acceptance motive calculated $16(9 \%)$ participants were very frequent, 23 (13\%) participants were frequent, 55 (24.2\%) participants were sometimes, and 44 (24.9\%) participants were seldom expressing bajingan. However, the remainder determined $44(24.9 \%)$ participants never expressed bajingan as their expletive.

Further, the number of females and males participants who expressed the expletive motives were comparable in Figure 1.This figure presented the number of females and males' expletive motives, as if the contributing criteria showed to be slightly narrow. Accordingly, in comparing the mean variances between females and males' criteria, five motives indicated into the following effects, such as anger expression(females' mean $=2.45, \mathrm{SD}=.794$; males' mean $=2.70, \mathrm{SD}=$ $.678, p<.051$ ), peer pressure (females' mean $=2.13$, $\mathrm{SD}=.959$; males' mean $=2.24, \mathrm{SD}=.960, p<.420)$, tensions and frustrations relief (females' mean $=2.17$, 
$\mathrm{SD}=.918$; males' mean $=2.42, \mathrm{SD}=.950, p<.570)$, part of acting cool (females' mean $=1.96, \mathrm{SD}=1.050$; males' mean $=2.64, \mathrm{SD}=1.146, p<.294)$, and society acceptance (females' mean $=2.57, \mathrm{SD}=1.288$; males' mean $=2.56, \mathrm{SD}=1.146, p<.270$ ). These motives were not significantly different.

Figure 1. Genders' Mean for Expletive Motives

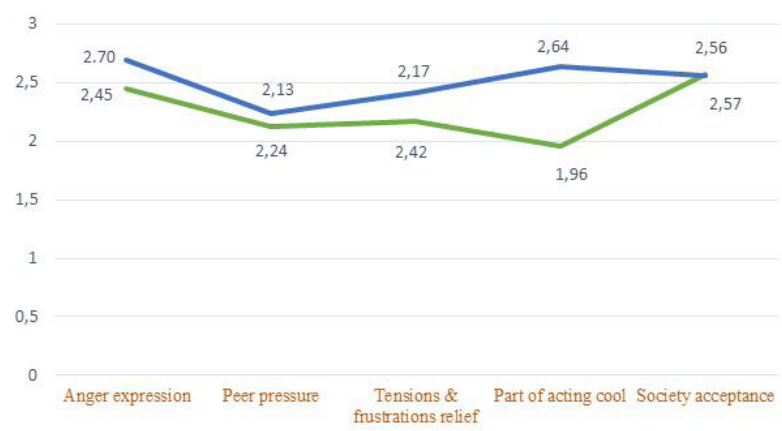

-Female

\section{Non-Parametric Analyses}

The Spearman's rho was analyzed to portray the correlation among five expletive motives, where $p<.01$ was set as the correlation parameter. The Spearman's rho was noteworthy to address that the society acceptance $(-.058,-.006$, and -.010$)$ negatively correlated with the anger expression, peer pressure, and tensions and frustrations relief respectively. However, the correlation motives were considerably high. In this respect, the correlation coefficients among the expletive motives were at $p<.01$ level for 2 -tailed prediction. The correlation coefficients were correspondingly $.274, .314, .390, .297$, .292 , and .245. As shown in Table 1, the correlations among the expletive motives were significant.

This research also analyzed the Chi-square goodness of fit test. This test identified the different categories $(p=.000)$. Table 2 established female's Chisquare statistics by its category. The females' Chi-square test of expletive motives were significant for anger expression, $\chi^{2}(4, n=127)=165.910, p<.000$; peer pressure, $\chi^{2}(4, n=127)=80.599, p<.000$; tensions and

Table 1. Spearman's Rho Correlation Coefficients among Expletive Motives

\begin{tabular}{|c|c|c|c|c|c|c|c|}
\hline & $\begin{array}{l}\text { Expletive } \\
\text { Motives }\end{array}$ & & $\begin{array}{c}\text { Anger } \\
\text { expression }\end{array}$ & $\begin{array}{c}\text { Peer } \\
\text { pressure }\end{array}$ & $\begin{array}{c}\text { Tensions \& } \\
\text { frustrations relief }\end{array}$ & $\begin{array}{c}\text { Part of } \\
\text { acting cool }\end{array}$ & $\begin{array}{c}\text { Society } \\
\text { acceptance }\end{array}$ \\
\hline \multirow{5}{*}{ 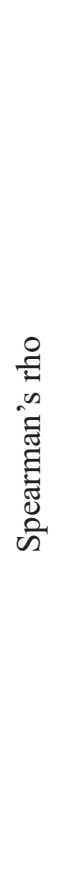 } & $\begin{array}{c}\text { Anger } \\
\text { expression }\end{array}$ & $\begin{array}{c}\text { Correlation } \\
\text { coefficient } \\
\text { Sig. (2-tailed) } \\
\text { N }\end{array}$ & $\begin{array}{l}1.000 \\
- \\
177\end{array}$ & $\begin{array}{c}.274 * * \\
.000 \\
177\end{array}$ & $\begin{array}{c}.314^{* *} \\
.000 \\
177\end{array}$ & $\begin{array}{l}.133 \\
.077 \\
177\end{array}$ & $\begin{array}{l}-.058 \\
.445 \\
177\end{array}$ \\
\hline & Peer pressure & $\begin{array}{c}\text { Correlation } \\
\text { coefficient } \\
\text { Sig. (2-tailed) } \\
\mathrm{N}\end{array}$ & $\begin{array}{c}.274 * * \\
.000 \\
177\end{array}$ & $\begin{array}{l}1.000 \\
- \\
177\end{array}$ & $\begin{array}{c}.390 * * \\
.000 \\
177\end{array}$ & $\begin{array}{c}.297 * * \\
.000 \\
177\end{array}$ & $\begin{array}{l}-.006 \\
.937 \\
177\end{array}$ \\
\hline & $\begin{array}{c}\text { Tensions \& } \\
\text { frustrations } \\
\text { relief }\end{array}$ & $\begin{array}{c}\text { Correlation } \\
\text { coefficient } \\
\text { Sig. (2-tailed) } \\
\text { N }\end{array}$ & $\begin{array}{c}.314 * * \\
.000 \\
177\end{array}$ & $\begin{array}{c}.390 * * \\
.000 \\
177\end{array}$ & $\begin{array}{l}1.000 \\
- \\
177\end{array}$ & $\begin{array}{c}.292 * * \\
.000 \\
177\end{array}$ & $\begin{array}{c}-.010 \\
.892 \\
177\end{array}$ \\
\hline & $\begin{array}{c}\text { Part of acting } \\
\text { cool }\end{array}$ & $\begin{array}{c}\text { Correlation } \\
\text { coefficient } \\
\text { Sig. (2-tailed) } \\
\text { N }\end{array}$ & $\begin{array}{l}.133 \\
.077 \\
177\end{array}$ & $\begin{array}{c}.297 * * \\
.000 \\
177\end{array}$ & $\begin{array}{c}.292 * * \\
.000 \\
177\end{array}$ & $\begin{array}{c}1.000 \\
- \\
177\end{array}$ & $\begin{array}{c}.245 * * \\
.001 \\
177\end{array}$ \\
\hline & $\begin{array}{c}\text { Society } \\
\text { acceptance }\end{array}$ & $\begin{array}{c}\text { Correlation } \\
\text { coefficient } \\
\text { Sig. (2-tailed) } \\
\mathrm{N}\end{array}$ & $\begin{array}{l}-.058 \\
.445 \\
177\end{array}$ & $\begin{array}{l}-.006 \\
.937 \\
177\end{array}$ & $\begin{array}{c}-.010 \\
.892 \\
177\end{array}$ & $\begin{array}{c}.245 * * \\
.001 \\
177\end{array}$ & $\begin{array}{c}1.00 \\
- \\
177\end{array}$ \\
\hline
\end{tabular}

\footnotetext{
**Correlation is significant at the .01 level (2-tailed), $p<.01$
} 
frustrations relief, $\chi^{2}(4, n=127)=87.379, p<.000$; part of acting cool, $\chi^{2}(4, n=127)=70.203, p<.000$; and society acceptance, $\chi^{2}(4, n=127)=25.175, p<.000$ in terms of the expletive motives.

Meanwhile, Table 3 presented males' Chi-square test of expletive motives that established a significant result accordingly, in which anger expression showed $\chi^{2}(3, n=50)=36.880, p<.000$; peer pressure, $\chi^{2}(3, n=$ $50)=8.560, p<.036$; tensions and frustrations relief, $\chi^{2}$ $(3, n=50)=7.760, p<.051$; part of acting cool, $\chi^{2}(4, n$ $=50)=12.200, p<.016$; and society acceptance, $\chi^{2}(4, n$ $=50)=13.600, p<.009$.

Furthermore, prior to applying for Mann-Whitney $\mathrm{U}$ test, a normality test resulted from the instrument that was in abnormal distribution $(p>.05)$ for the expletive motives, namely: anger expression, peer pressure, tensions and frustrations relief, part of acting cool, and society acceptance. Out of five expletive motives, four motives were not significant differences, unless part of acting cool that was indicated to have a difference significantly $(p=.000)$. As shown in Table 4 , females and males' expletive statistically referred to the means across the motives (anger expression, $\mathrm{U}=2642.500, p=$ .056 ; peer pressure, $\mathrm{U}=2919.000, p=.382$; tensions and frustrations relief, $\mathrm{U}=2717.500, p=.117$; part of acting cool, $\mathrm{U}=2117.500, p=.000$; and society acceptance, $\mathrm{U}$ $=3108.000, p=.822$ ).

As shown in Table 5 , the negative $Z$ value $(Z=$

Table 2. Females' Chi-Square Test of Expletive Motives

\begin{tabular}{|c|c|c|c|c|c|}
\hline & Anger expression & Peer pressure & $\begin{array}{c}\text { Tensions \& } \\
\text { frustrations relief }\end{array}$ & $\begin{array}{c}\text { Part of acting } \\
\text { cool }\end{array}$ & $\begin{array}{c}\text { Society } \\
\text { acceptance }\end{array}$ \\
\hline Chi-Square & $165.910^{\mathrm{a}}$ & $80.599^{\mathrm{a}}$ & $87.379^{\mathrm{a}}$ & $70.203^{\mathrm{a}}$ & $25.175^{\mathrm{a}}$ \\
\hline $\mathrm{df}$ & 4 & 4 & 4 & 4 & 4 \\
\hline Asymp. Sig. & .000 & .000 & .000 & .000 & .000 \\
\hline
\end{tabular}

a. 0 cells $(.0 \%)$ have expected frequencies less than 5 ; the minimum expected cell frequency is $35.4 ; n=127$

Table 3. Males' Chi-Square Test of Expletive Motives

\begin{tabular}{|c|c|c|c|c|c|}
\hline & Anger expression & Peer pressure & $\begin{array}{c}\text { Tensions \& } \\
\text { frustrations relief }\end{array}$ & $\begin{array}{c}\text { Part of acting } \\
\text { cool }\end{array}$ & $\begin{array}{c}\text { Society } \\
\text { acceptance }\end{array}$ \\
\hline Chi-Square & $36.880^{\mathrm{a}}$ & $8.560^{\mathrm{a}}$ & $7.760^{\mathrm{a}}$ & $12.200^{\mathrm{b}}$ & $13.600^{\mathrm{b}}$ \\
\hline $\mathrm{df}$ & 3 & 3 & 3 & 4 & 4 \\
\hline Asymp. Sig. & .000 & .036 & .051 & .016 & .009 \\
\hline
\end{tabular}

a. 0 cells $(.0 \%)$ have expected frequencies less than 5 ; the minimum expected cell frequency is $12.5 ; n=50$

b. 0 cells $(.0 \%)$ have expected frequencies less than 5 ; the minimum expected cell frequency is $10.0 ; n=50$

Table 4. Females and Males' Perception through Mann-Whitney U Tests

\begin{tabular}{|c|c|c|c|c|}
\hline Expletive Motives & $\mathrm{U}$ & $\mathrm{df}$ & Mean difference & $\begin{array}{c}\text { Sig. } \\
(2 \text {-tailed })\end{array}$ \\
\hline Anger expression & 2642.500 & .769 & 2.52 & .056 \\
\hline Peer pressure & 2919.000 & .958 & 2.16 & .382 \\
\hline Tensions \& frustrations relief & 2717.500 & .931 & 2.24 & .117 \\
\hline Part of acting cool & 2117.500 & 1.115 & 2.15 & $.000^{*}$ \\
\hline Society acceptance & 3108.000 & 1.247 & 2.56 & .822 \\
\hline
\end{tabular}

$* p<.05$. 
Table 5. Mann-Whitney U Tests' Expletive Motives

\begin{tabular}{|c|c|c|c|c|c|}
\hline Test Statistics $^{\mathrm{a}}$ & Anger expression & Peer pressure & $\begin{array}{c}\text { Tensions \& } \\
\text { frustrations relief }\end{array}$ & $\begin{array}{c}\text { Part of acting } \\
\text { cool }\end{array}$ & $\begin{array}{c}\text { Society } \\
\text { acceptance }\end{array}$ \\
\hline Mann-Whitney U & 2642.500 & 2919.000 & 2717.500 & 2117.500 & 3108.000 \\
\hline Wilcoxon W & 10770.500 & 11047.000 & 10845.500 & 10245.500 & 11236.000 \\
\hline Z & -1.910 & -.875 & -1.567 & -3.607 & -.225 \\
\hline $\begin{array}{c}\text { Asymp. Sig. } \\
\text { (2-tailed) }\end{array}$ & .056 & .382 & .117 & .000 & .822 \\
\hline
\end{tabular}

a. Grouping Variable: Sex

-1.910) for anger expression, $(Z=-.875)$ for peer pressure, $(Z=-1.567)$ for tensions and frustrations relief, $(Z=$ -3.607) for part of acting cool, and $(Z=-.225)$ for society acceptance determined that the rank sums were lower than the expected values. The lower rank sums of the expletive motives showed that there was a significant difference between the part of acting cool toward the participants' perception $(p=.000)$. Conversely, other four expletive motives, namely: anger expression $(p=.056)$, peer pressure $(p=.382)$, tensions and frustrations relief $(p=.117)$, and society acceptance $(p=.822)$ were not significantly different. Meanwhile, the Mann-Whitney U test addressed a significant difference $(p<.05)$, which was due to the part of acting cool. Hence, other four expletive motives were not significantly different $(p>.05)$.

In the furtherance, this research also analyzed males and females' perception of relevance to the polysemous word of bajingan. Figure 2 gave the comparably polysemous word in genders-base perception in touch with participants' past experience upon this word. Relating to the understanding of this word, both males and females accordingly had their own interpretation. To be directly appropriate in comprehending this polysemy, one research question of "Can students definitely differentiate the polysemy of bajingan?" attempted to verify the definite meanings which were connectable into the particular condition by male and female participants. Pointing the facts, 18 (10.2\%) females acknowledged bajingan as the wagon driver (as a profession) and 124 (70\%) females deliberately decided bajingan as an expletive. On the other hand, $13(.7 \%)$ males determined this polysemy word as the wagon driver and 44 (25\%) males familiarly thought that this word was an expletive. However, these polysemous meanings ranked the highest position among females.

\section{Figure 2. Participants' Perception upon Bajingan}

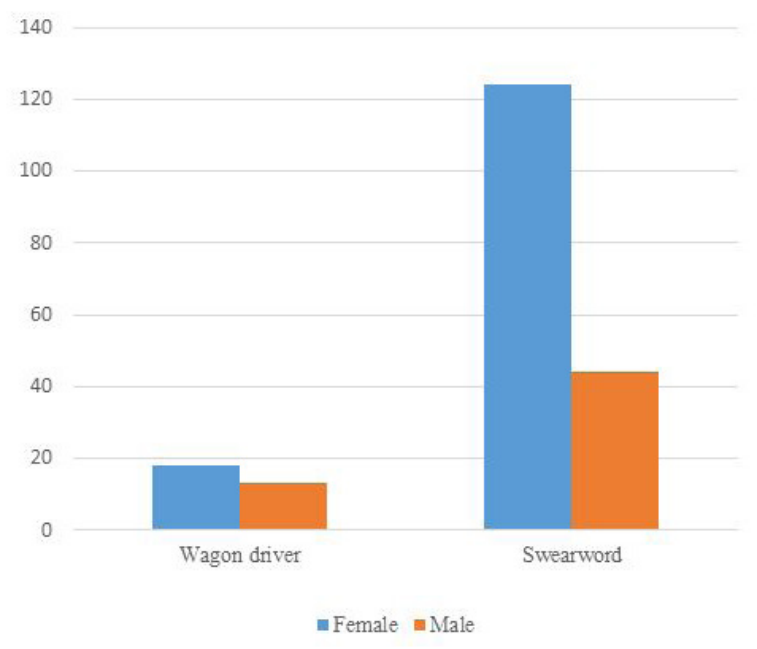

Another analysis regarding the expletive motives constituted the gender-based groups who frequently used this word. This analysis compared either males or females versus mixed-gender expressions. Empirically, males showed a predominant expletive more than females towards males and mixed gender frequently. Next, both females and males slightly swore in females group and their expletives were not parted from the stereotypical backgrounds. These backgrounds implicated to a stronger expletive when females conflicted with males. Figure 3 addressed that females swore more than twice in both males and mixed group. 86 females conveyed this expletive to males group, as comparable with 30 males who swore lower. Then, 7 females expressed bajingan towards females group and only 1 male perceived this issue. Regarding the mixed group, 39 females and 19 males showed their expletive to both genders when expressing anger. This consequence reported that 127 
(72\%) females and 50 (28\%) males completely returned the questionnaires.

\section{Figure 3. Gender Group Frequently Used in Expletive}

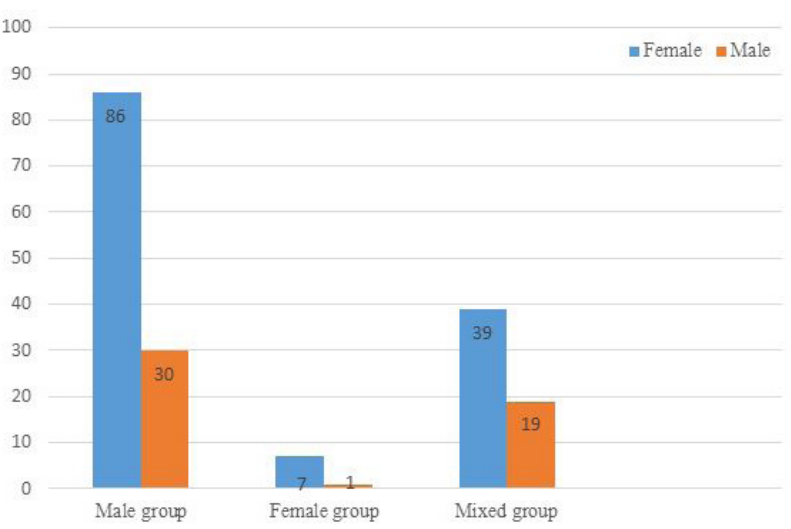

Being confirmed this expletive, there was no longer exclusively dominated by the males in conveying the motives. Firstly, both sexes addressed a wide expression of their expletive through the TV program as the most influential media. Figure 4 seemingly indicated that 75 females and 26 males ranked the highest rate of this expletive engaged in the experiential conversations. Secondly, other reasons concerning with the music, friends, colleagues, and social environments contributed a reasonable decision upon 53 females who posted the second rank of their expletive experience. However, the daily environmental relevance and engagement in social relationships with the online connection influentially portrayed participants' expletive contribution. Meanwhile, 12 males were familiar with the word of bajingan as an expletive through music, friends, colleagues, and social environments. Thirdly, the internet facility dominated the third position among 36 females and 23 males to express this expletive. Fourthly, the cinema had ranked the fourth position among 21 females and 14 males to be familiar with this expletive. Fifthly, the printed sources like newspapers, tabloids, and novels had influenced 14 females and 7 males to have this expletive. Last but not least, the radio brought about the lowest position towards 4 females and 6 males in expressing bajingan. Figure 3 showed that females ranked the higher position than males in expressing their expletive. These facts recorded the composition of females' rating with 127 (72\%) and 50 (28\%) for males respectively. This composition was due to the personal experience formed in the societal milieu. In this regard, the results had a significant difference, in which females were mostly provoked to express bajingan.
Figure 4. Media Mostly Influenced the Participants to Swear

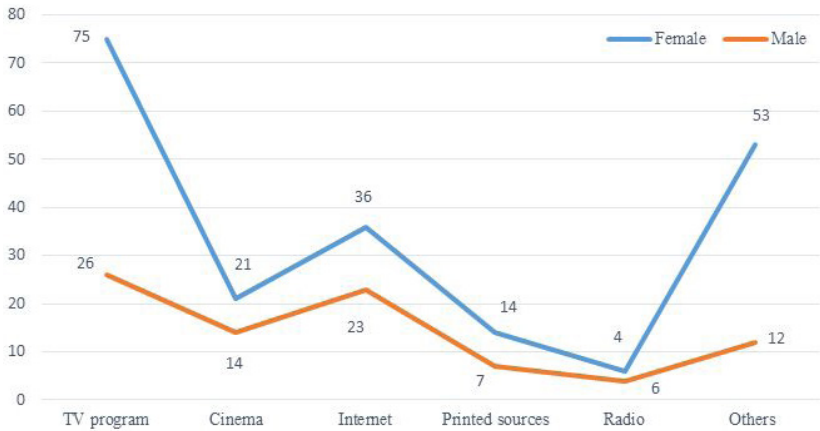

\section{CONCLUSION}

The expletive is generally associated with the anger expression, peer pressure, tensions and frustrations relief, part of acting cool, and society acceptance motives. These identifiable motives are found in participants' daily communications, cultures and defined gender perspectives as created in the social linkages. In accordance with the polysemous meaning of bajingan, both female and male participants responded the anger expression and society acceptance rank the top of five motives in this research. First, the anger expression achieves 2.70 for males' mean and 2.45 for females' mean, whereas the society acceptance achieves 2.56 for males' mean and 2.57 for females' mean. Second, the participants definitely enable themselves to differentiate the polysemous meaning of bajingan. The individual experience between female and male participants record that $10.2 \%$ females understood the word of bajingan as a wagon driver and $70 \%$ females believe the word as an expletive, whilst the remainders do not indicate the polysemous meaning. On the other hand, $.7 \%$ male participants responded this word as a wagon driver and other $25 \%$ participants definitely determine as an expletive. Contingently, for the remainders do not confirm their understanding on this word. Third, the male participants frequently experience with a more predominant expletive expression than females, as recorded on the gender-based groups. Alternatively, both females and males slightly showed their expletive in females group due to the stereotype backgrounds. Fourth, the participants have got the expletive expression through the TV program, cinema, internet, printed sources, radio, and other sources (music, friends, colleagues, and social environments). However, the TV program is the most 
influential media among the participants to be familiar with the word of bajingan. This experience is undertaken from 75 females and 26 males who increase the highest rate of the expletive expression into their experiential talks or conversations.

As granted in the social phenomena, this expletive deals with the intra-and inter-individual contexts and deduces positive or negative reactions collectively. This research implicates the influential perception on bajingan as if this word determines participants' judgment-based experience by following the rating method only. The influencing motives accordingly refer to Scherer and Sagarin's swearing motives, in which five motives, namely: anger expression, peer pressure, tensions and frustrations relief, part of acting cool, and society acceptance has measured and determined participants' experiential life when expressing bajingan. Hence, this research is also aware of being the subjective intervention that potentially influences the participants in completing the research instruments.

\section{REFERENCES}

Anderson, L. G., \& Trudgill, P. (1990). Bad language. London: Penguin Books, Ltd.

Anderson, L. G., \& Trudgill, P. (2007). Swearing. In L. Monaghan. \& J. Goodman (Ed.) (Ed.), A cultural approach to interpersonal communication (pp. 195199). Oxford: Blackwell.

Andrason, A., \& van der Merwe, C. H. J. (2015). The semantic potential of verbal conjugations as a set of polysemous senses: The Qatal in Genesis. Hebrew Studies, 56, 71-88.

Ary, D., Jacobs, L. C., \& Sorensen, C. K. (2010). Introduction to research in education (8th ed.). Belmont: Wadsworth, Cengage Learning.

Bowers, J. S., \& Pleydell-Pearce, C. W. (2011). Swearing, euphemisms, and linguistic relativity. Plos One, 6(7), 1-8. https://doi.org/10.1371/journal.pone.0022341

Butler, T. (2010). Swearing Justice in Henry Goodcole and The Witch of Edmonton. Studies in English Literature, 50(1), 127-145.

Cronbach, L. J. (2004). My current thoughts on Coefficient Alpha and successor procedures. Educational and Psychological Measurement, 64, 391-418.

Crossley, S., Salsbury, T., \& McNamara, D. (2010). The development of polysemy and frequency use in English second language speakers. A Journal of Research in Language Studies, 60(3), 573-605. https://doi.org/10.1111/j.1467-9922.2010.00568.x

Dewaele, J.-. M. (2004). The emotional force of swearwords and taboo words in the speech of multilingual. Journal of Multilingual and Multicultural Development,
25(2/3), 204-222.

Dynel, M. (2012). Swearing methodology: The (im) politeness expletives in anonymous commentaries on youtube. Journal of English Studies, 10, 25-50.

Elston-Güttler, K. E., \&Williams, J. N. (2008). First language polysemy affects second language meaning interpretation: Evidence for activation of first language concepts during second language reading. Second Language Research, 42(2), 167-187. https:// doi.org/10.1177/0267658307086300

Fägersten, K. B.-. (2007). Swear word offensiveness. Saarland Working Papers in Linguistics (SWPL), 1, 14-37.

Gati, P. (2014). The use of swear words by women: A study of single-sex and mixed-sex conversations. Halmstad University. Retrieved from http://www.diva-portal. org/smash/get/diva2:786175/FULLTEXT01.pdf

Group, T. F. (2005). Language and Sexual Imagery in Broadcasting: A Contextual Investigation. Retrieved September 25, 2016, from https://www.ofcom.org. uk/_data/assets/pdf_file/0012/24015/language.pdf

Hagen, S. H. (2013). Swearwords and attitude change: A sociolinguistic study. The University of Bergen. Retrieved from http://bora.uib.no/bitstream/ handle/1956/7270/106782449.pdf?sequence $=1$

Hoffman, P., Ralph, M. A. L., \& Rogers, T. T. (2013). Semantic diversity: A measure of semantic ambiguity based on variability in the contextual usage of words. Behavior Research Methods, 45(3), 718-730. https:// doi.org/10.3758/s13428-012-0278-x

Jay, T., \& Janschewitz, K. (2008). The pragmatics of swearing. Journal of Politeness Research, 4, 267 288. https://doi.org/10.1515/JPLR.2008.013

Jay, T. (2009). The utility and ubiquity of taboo words. Association for Psychological Science, 4(2), 153-161.

Johnson, D. I., \& Lewis, N. (2010). Perceptions of swearing in the work setting: An expectancy violations theory perspective. Communication Reports, 23(2), 106118. https://doi.org/10.1080/08934215.2010.511401

Karjalainen, M. (2002). Where have all the swearwords gone? An analysis of the loss of swear words in two Swedish translations of J. D. Salinger's Catcher in the Rye. The University of Helsinki. Retrieved from http://ethesis.helsinki.fi/julkaisut/hum/engla/ $\mathrm{pg} / \mathrm{karjalainen/wherehav.pdf}$

Khanna, M. M., \& Cortese, M. J. (2011). Age of acquisition estimates for 1,208 ambiguous and polysemous words. Behavior Research Methods, 43(1), 89-96. https://doi.org/10.3758/s13428-010-0027-y

Lantto, H. (2014). Code-switching, swearing, and slang: The colloquial register of Basque in Greater Bilbao. International Journal of Bilingualism, 18(6), 633 648. https://doi.org/10.1177/1367006912457274

Livni, E. (2016). A linguist's love letter to profanity explains 
why it's fine to curse around kids. Retrieved from http://qz.com/791736/a-linguists-love-letter-toprofanity-explains-why-its-fine-to-crse-around-kids/

Manchón, P. G. (2013). A corpus-based analysis of swearword translation in DVD subtitles and internet fansubs. Universidad Complutense. Retrieved from https://eprints.ucm.es/23201/1/Paula_Garcia Manchón_\%282\%29.pdf

Mensah, E. O. (2012). Youth language in Nigeria: A case study of the Ágábá Boys. Sociolinguistic Studies, 6(3), 387-419. https://doi.org/10.1558/sols.v6i3.387

Mercury, R.-E. (1995). Swearing: A "bad" part of language; a good part of language learning. TESL Canada Journal/ Revue TESL Du Canada, 13(1), 28-36.

Neuman, W. L. (2006). Social research methods: Qualitative and quantitative approaches (6th ed.). Boston: Pearson Education, Inc.

Nicolau, M. Fe. S., \& Sukamto, K. E. (2013). Male and female attitudes towards swear words: A case study at Binus International School. K@ta, 16(2), 71-76. https://doi.org/10.9744/kata.16.2.71-76

Pavlenko, A. (2008). Emotion and emotion-laden words in the bilingual lexicon. Bilingualism: Language and Cognition, 11(2), 147-164. https://doi.org/10.1017/ S1366728908003283

Peregrin, J. (2010). Inferentializing Semantics. Journal of Philosophical Logic, 39(3), 255-274. https://doi. org/10.1007/s10992-010-9123-9
Praschinger, A., Pomikal, C., \& Stieger, S. (2011). May I curse a referee? Swear words and consequences. Journal of Sports Science and Medicine, 10, 341-345.

Razavi, A. H., Inkpen, D., Uritsky, S., Matwin, S. (2010). Offensive language detection using multi-level classification. In A. F. Kešelj (Ed.) (Ed.), Advances in Artificial Intelligence (pp. 16-27). Ottawa: ResearchGate https://doi.org/10.1007/978-3-64213059-5_5

Scherer, C. R., \& Sagarin, B, J. (2006). Indecent influence: The positive effects of obscenity on persuasion. Social Influence, 1(2), 138-146. https://doi. org/10.1080/15534510600747597

Shallu., \& Gupta, V. (2013). A survey of word-sense disambiguation effective techniques and methods for Indian languages. Journal of Emerging Technologies In Web Intelligence, 5(4), 354-360. https://doi. org/10.4304/jetwi.5.4.354-360

Stevens, J. P. (2009). Applied multivariate statistics for the social sciences (5th ed.). New York: Taylor \& Francis Group, LLC.

Verspoor, M., \& Lowie, W. (2003). Making sense of polysemous words. Language Learning, 53(3), 547-586.

Vingerhoets, A. J. J. M., Bylsma, L. M., \& De Vlam, C. (2013). Swearing: A biopsychosocial perspective. Psychological Topics, 22(2), 287-304. 